\title{
Sperm Morphology and DNA Integrity of Frozen Thawed Buffalo Semen Treated with Heparin Binding Protein
}

\author{
Yanben M. Kikon ${ }^{1}$, K. Loganathasamy ${ }^{2 *}$, V.S. Gomathy ${ }^{3}$ and K. Vijayarani ${ }^{4}$ \\ ${ }^{1}$ Department of Veterinary Physiology, Madras Veterinary College, \\ Chennai-600 007, Tamil Nadu, India \\ ${ }^{2}$ Department of Veterinary Physiology and Biochemistry, Veterinary College and Research \\ Institute, Tirunelveli-627 358, Tamil Nadu, India \\ ${ }^{3}$ Department of Veterinary Physiology, Madras Veterinary College, \\ Chennai-600 007, Tamil Nadu, India \\ ${ }^{4}$ Department of Bioinformatics and ARIS Cell, Madras Veterinary College, \\ Chennai-600 007, Tamil Nadu, India \\ *Corresponding author
}

\section{A B S T R A C T}

\section{Keywords}

Heparin binding protein,

Morphology, DNA

integrity,

Spermatozoa,

Buffalo semen

\section{Article Info}

Accepted:

22 June 2020

Available Online:

10 July 2020
The present study was conducted to assess the sperm morphology and DNA integrity of frozen thawed buffalo semen treated with heparin binding protein (HBP). Buffalo semen straws from 10 bulls were procured from Central Frozen Semen Production and Training Institute, Hesseraghatta, Banglore-560088. The frozen straws were thawed at $37^{\circ} \mathrm{C}$ for 30 seconds and emptied into a $15 \mathrm{~mL}$ sterile plastic centrifuge tube containing $1 \mathrm{~mL}$ capacitation medium (control), addition of $25 \mu \mathrm{g} / \mathrm{mL}$ (treatment I), $50 \mu \mathrm{g} / \mathrm{mL}$ (treatment II) and $100 \mu \mathrm{g} / \mathrm{mL}$ (treatment III) of HBP. The contents were incubated at $37^{\circ} \mathrm{C}$ for 2 hours. After incubation, the sperm morphology was determined by Rose Bengal stain technique. Morphologically normal sperm in control, HBP treatment I, II and III were $86.70 \% \pm 1.52$, $87.00 \% \pm 1.21,87.00 \% \pm 1.28$ and $86.55 \% \pm 1.59$ respectively. There was no significant difference between control and HBP treatments with respect to sperm morphology. The sperm DNA integrity was assessed by acridine orange stain method. There was no significant difference among control $(90.15 \% \pm 1.14)$, HBP treatment I $(90.25 \% \pm 1.25)$, II $(89.85 \% \pm 1.05)$ and III $(90.40 \% \pm 1.16)$ with respect to sperm DNA integrity. This study indicated that HBP supplementation in capacitation medium did not alter the sperm morphology and DNA integrity.

\section{Introduction}

Cryopreservation of semen is an important tool for assisted reproductive techniques (ARTs) and is the most efficient way for storing germ plasma (Olaciregui et al., 2014).
Cryopreservation has been applied to various species, including human, cattle, swine, dogs and cats (Mota Filho et al., 2006). Although sperm cryopreservation preserves sperm motility, metabolic functions and fertility, still the freeze-thawing process causes irreversible 
damage to spermatozoa and reduces fertility (Ardon and Saurez, 2013).Reduced efficiency of AI in buffaloes has necessitated to find out the factors that contribute to the infertility. Several studies have been conducted in the past decades in search of exact potential fertility markers in bulls. The influence of seminal proteins on male reproduction has always drawn attention because many studies proved that their expression is associated with fertility scores in dairy cattle (Cancel et al., 1997), beef cattle (Parent et al., 1999) and horses (Brandon et al., 1999). Further studies in this field may help to design accurate measures in AI technology for augmenting the reproductive performance.

Seminal proteins mediate the binding of sperm cells to oviductal epithelium and preserve membrane integrity by exerting the inhibitory effects on the mitochondrial activity and metabolism to conserve energy needed until fertilization as well as to minimize the production of reactive oxygen species (ROS) and lipid peroxidation (LPO) of sperm membrane (Schoneck et al., 1996). Seminal proteins also have activities in antiapoptosis and cell survival (Chakraborty et al., 2006 and Rangaswami et al., 2006). A number of seminal plasma proteins have been investigated which act as molecular markers of fertility in different species (Jonakova et al., 2010). Interestingly, proteomics has identified large number of proteins that are differentially expressed in sperm membrane, seminal plasma, accessory sex gland fluid and epididymal fluid in case of both fertile and sub-fertile bulls (Amours et al., 2010). Proteins such as osteopontin (OPN), prostaglandin D synthase, bovine seminal plasma proteins (BSP A1, A2 and A3), heparin binding proteins (HBPs), fertility associated antigen (FAA),phospholipase A2, sperm adhesion Z13, clusterin and heat shock proteins (HSPs) have been reported as indicators of fertility (Fouchecourt et al.,
2000; Sprott et al., 2000; McCauley et al., 2001 and Moura et al., 2006).

Bovine spermatozoa that have been exposed to seminal plasma possess more binding sites for heparin than the cauda epididymal fraction of sperms, which have not exposed to seminal plasma. A common feature of most seminal plasma proteins is their ability to interact with different types of inorganic and organic materials present in seminal fluid (Cameron et $a l ., 2007)$. Some of these proteins are bound to the sperm surface during ejaculation and thus protein-coating layers are formed (Varilova et al.,2006).Seminal fluid HBPs are supposed to attach themselves to the sperm surface, especially lipids containing phosphoryl-choline group, thus allowing heparin-like glycosaminoglycans in the female reproductive tract to activate the sperm capacitation (Miller et al., 1987). Thus, seminal fluid HBPs play a vital role in spermatozoon survival and overall fertilization process and any alteration in these proteins can be directly related to infertility. Heparin alone cannot capacitate epididymal spermatozoa. However, when accessory gland proteins that bind heparin are added to epididymal spermatozoa, these spermatozoa are able to undergo capacitation and bind to the $\mathrm{ZP}$ with increase in acrosome reaction (Miller et al., 1990). HBPs allow spermatozoa to face the challenge of stress by lysophosphatidyl-choline and undergo the acrosome reaction (Lane et al., 1999). HBPs were also found to modulate capacitation and zona binding ability of buffalo epididymal spermatozoa (Arangasamy et al., 2005).

Ejaculated bovine sperm have more heparin binding sites than epididymal sperm and exposure of epididymal sperm to seminal plasma increases the number of heparin binding sites on the sperm (Lee et al., 1985).Sperm surface properties are 
dramatically altered during epididymal maturation and at ejaculation by the removal or addition of a variety of proteins and lipid constituents, and sperm surface components play an important role in capacitation of sperm (Yanagimachi, 1988 and Saling, 1989). HBPs protect sperm from stress of freezing and thawing and maintained intracellular protein homeostasis (Shi et al., 1998). HBPs themselves bind to spermatozoal membrane to make it stable (Manjunath and Therien, 2002). Mogielnicka and Korden, 2011 indicated that zona binding proteins of boar seminal plasma have a shielding effect on the plasma membrane and the acrosome of spermatozoa by protecting their structures against the damage caused by cold shock.

\section{Materials and Methods}

\section{Materials}

All the plasticware used in this study were purchased from Tarson, India. All the glassware used in this study were purchased from Borosil, India. All chemicals used in this study were procured from Sigma-Aldrich chemicals Co., USA.

\section{Methods}

\section{Capacitation stock solution}

Capacitation stock solution / Sperm TALP was prepared as detailed below.

\begin{tabular}{|c|c|}
\hline Components & For $\mathbf{1 0 0 0} \mathbf{~ m L}$ (in mM) \\
\hline Sodium chloride $(\mathrm{NaCl})$ & 114 \\
\hline Potassium chloride $(\mathrm{KCl})$ & 3.2 \\
\hline Calcium chloride $\left(\mathrm{CaCl}_{2} \cdot 2 \mathrm{H}_{2} \mathrm{O}\right)$ & 2.0 \\
\hline Magnesium chloride $\left(\mathrm{MgCl}_{2} \cdot 6 \mathrm{H}_{2} \mathrm{O}\right)$ & 0.5 \\
\hline Sodium dihydrogen orthophosphate & 0.34 \\
\hline $\begin{array}{c}\left(\mathrm{NaH}_{2} \mathrm{PO}_{4} \cdot \mathrm{H}_{2} \mathrm{O}\right) \\
\text { Sodium lactate }(60 \% \text { syrup})\end{array}$ & $1.86 \mu \mathrm{L} / \mathrm{mL}$ \\
\hline Phenol red & $10 \mu \mathrm{g} / \mathrm{mL}$ \\
\hline
\end{tabular}

Pyruvate stock solution

\begin{tabular}{|c|c|}
\hline Sodium pyruvate & $\begin{array}{c}22 \mathrm{mg} / 10 \mathrm{~mL} \\
\text { capacitation medium }\end{array}$ \\
\hline
\end{tabular}

Heparin stock solution

\begin{tabular}{|c|c|}
\hline Heparin & $\begin{array}{c}5 \mathrm{mg} / 10 \mathrm{~mL} \\
\text { capacitation medium }\end{array}$ \\
\hline
\end{tabular}

Gentamicin stock solution

\section{Gentamicin $\quad 50 \mathrm{mg} / \mathrm{mL}$ in saline}

All the stock solutions were filter sterilized $(0.2 \mu \mathrm{m})$ and stored at $4^{\circ} \mathrm{C}$ until use. 


\section{Capacitation working solution}

\begin{tabular}{|l|c|}
\hline \multicolumn{1}{|c|}{ Components } & For $\mathbf{1 0} \mathbf{~ m L}$ \\
\hline Capacitation stock solution & $9.5 \mathrm{~mL}$ \\
\hline Pyruvate stock solution & $0.1 \mathrm{~mL}$ \\
\hline Heparin stock solution & $0.4 \mathrm{~mL}$ \\
\hline Gentamicin stock solution & $10 \mu \mathrm{L}$ \\
\hline Bovine serum albumin (Fatty acid free) & $60 \mathrm{mg}$ \\
\hline
\end{tabular}

The working solution was prepared freshly, filter sterilized $(0.2 \mu \mathrm{m})$ and pre-warmed at $37^{\circ} \mathrm{C}$ for 30 minutes before use. $\mathrm{pH}$ and osmolality of the stock and working medium were maintained at 7.6-7.8 and 280-300 mOsm, respectively.

\section{Sperm preparation}

Frozen semen straws from ten buffalo bulls were procured from Central Frozen Semen
Production and Training Institute, Hesseraghatta, Banglore-560088. The straws were collected in liquid nitrogen $\left(\mathrm{LN}_{2}\right.$ at -196 ${ }^{\circ} \mathrm{C}$ ) container, transported and stored in the semen bank of Madras Veterinary College, Chennai- 600 007.The frozen straws were thawed at $37^{\circ} \mathrm{C}$ for 30 seconds and emptied into $15 \mathrm{~mL}$ sterile plastic centrifuge tube containing $1 \mathrm{~mL}$ of capacitation medium and treated as below

\begin{tabular}{|c|c|}
\hline Experimental groups & Method of treatment \\
\hline Control & Capacitation medium alone (sperm TALP) \\
\hline Treatment I & $\begin{array}{l}\text { Capacitation medium }+ \text { Heparin binding protein } \\
(\mathrm{HBP}-25 \mu \mathrm{g} / \mathrm{mL})\end{array}$ \\
\hline Treatment II & $\begin{array}{l}\text { Capacitation medium }+ \text { Heparin binding protein } \\
(\mathrm{HBP}-50 \mu \mathrm{g} / \mathrm{mL})\end{array}$ \\
\hline Treatment III & $\begin{array}{l}\text { Capacitation medium }+ \text { Heparin binding protein } \\
(\mathrm{HBP}-100 \mu \mathrm{g} / \mathrm{mL})\end{array}$ \\
\hline
\end{tabular}

The contents were incubated at $37^{\circ} \mathrm{C}$ for 2 hours. After incubation, the sperm acrosome integrity and mitochondrial membrane potential (MMP) were assessed.

\section{Evaluation of sperm morphology}

Sperm morphology was assessed by Rose Bengal stain. $250 \mu 1$ semen was emptied into a separate eppendorf tube containing $500 \mu \mathrm{l}$ of Tris buffer and then 3 drops of Rose Bengal stain was added. The contents were centrifuged at 2000-3000 rpm for 3 minutes.
Then $1 \mathrm{~mL}$ Tris buffer was added. Again, the contents were centrifuged at 2000-3000 rpm for 3 minutes. Supernatant was removed. Finally $100 \mu$ Tris buffer was added. One drop of the well mixed sample was placed on a clean grease free glass slide and covered with cover slip. Spermatozoa were observed under40X. Spermatozoa showing head, midpiece and tail abnormalities were included in total abnormalities. A minimum of 200 spermatozoa were observed (Enciso et al., 2011). 


\section{Evaluation of sperm DNA integrity}

DNA integrity of sperm was assessed by using acridine orange staining. Semen samples were smeared on glass slides and airdried. Then, the smears were fixed with Carnoy's solution (1 part glacial acetic acid: 3 parts methanol) for 2 hours. After fixation, smears were air-dried and stained with freshly prepared acridine orange stain $(0.19 \mathrm{mg} / \mathrm{mL})$ for 5 minutes in the dark. After staining, smears were washed with distilled water and immediately evaluated under a fluorescent microscope at excitation wavelength of 450$490 \mathrm{~nm}$. An average of 200 sperm were counted on each slide and the duration of evaluation was 40 seconds per field. Sperm with normal DNA content showed green fluorescence whereas sperm with damaged DNA content appeared as a spectrum of yellow-green to red (Chohan et al., 2004).

\section{Statistical analysis}

The statistical analysis was carried out by IBM, SPSS version 20.0 for windows. The percentage value of variables was converted into Arsine value before performing one way analysis of variance (ANOVA).

\section{Results and Discussion}

\section{Effect of HBP on sperm morphology}

The sperm morphology was determined by Rose Bengal stain technique. Table 1 indicates that effect of HBP supplementation to sperm TALP on sperm morphology. Morphologically normal sperm in control, HBP treatment I, II and III were $86.70 \% \pm$ $1.52,87.00 \% \pm 1.21,87.00 \% \pm 1.28$ and $86.55 \% \pm 1.59$ respectively. There was no significant difference between control and HBP treatments with respect to sperm morphology.

\section{Effect of HBP on sperm dna integrity}

The sperm DNA integrity was assessed by Acridine orange stain method. Table 2 shows that effect of HBP supplementation to sperm TALP on DNA integrity.

There was no significant difference among control $(90.15 \% \pm 1.14)$, HBP treatment I $(90.25 \% \pm 1.25)$, II $(89.85 \% \pm 1.05)$ and III $(90.40 \% \pm 1.16)$ with respect to sperm DNA integrity.

Table.1 Effect of HBP supplementation on sperm morphology of frozen thawed buffalo semen

\begin{tabular}{|c|c|c|}
\hline Groups & $\begin{array}{c}\text { Normal spermatozoa } \\
(\% \pm S E)\end{array}$ & $\begin{array}{c}\text { Abnormal } \\
\text { spermatozoa } \\
(\% \pm \mathrm{SE})\end{array}$ \\
\hline Control & $86.70 \pm 1.52$ & $13.30 \pm 1.52$ \\
\hline Treatment I (HBP-25 $\mu \mathrm{g} / \mathrm{mL})$ & $87.00 \pm 1.21$ & $13.00 \pm 1.21$ \\
\hline Treatment II $(\mathrm{HBP}-50 \mu \mathrm{g} / \mathrm{mL})$ & $87.00 \pm 1.28$ & $13.00 \pm 1.28$ \\
\hline Treatment III (HBP-100 $\mu \mathrm{g} / \mathrm{mL})$ & $86.55 \pm 1.59$ & $13.45 \pm 1.59$ \\
\hline
\end{tabular}

Mean with different superscripts ( $\mathrm{a}$ and $\mathrm{b}$ ) in a column are significantly different $(\mathrm{P}<0.05)$ between groups. Data are presented as mean $\% \pm \mathrm{SE}$ 
Table.2 Effect of HBP supplementation on sperm dna integrity of frozen thawed buffalo semen

\begin{tabular}{|c|c|c|}
\hline Groups & $\begin{array}{c}\text { Spermatozoa with DNA } \\
\text { integrity }(\% \pm \mathrm{SE})\end{array}$ & $\begin{array}{l}\text { Spermatozoa without } \\
\text { DNA integrity }(\% \pm \mathrm{SE})\end{array}$ \\
\hline Control & $90.15 \pm 1.14$ & $9.85 \pm 1.14$ \\
\hline Treatment I (HBP-25 $\mu \mathrm{g} / \mathrm{mL})$ & $90.25 \pm 1.25$ & $9.75 \pm 1.25$ \\
\hline Treatment II (HBP-50 $\mu \mathrm{g} / \mathrm{mL})$ & $89.85 \pm 1.05$ & $10.15 \pm 1.05$ \\
\hline Treatment III (HBP-100 $\mu \mathrm{g} / \mathrm{mL})$ & $90.40 \pm 1.16$ & $9.60 \pm 1.16$ \\
\hline
\end{tabular}

Mean with different superscripts $(\mathrm{a}$ and $\mathrm{b})$ in a column are significantly different $(\mathrm{P}<0.05)$

between groups. Data are presented as mean $\% \pm \mathrm{SE}$

\section{Effect of HBP on sperm morphology}

HBP supplementation has no direct effect on sperm morphology This study was in accordance with the results of Enciso et al.(2011) who stated that major sperm abnormalities might have a genetic origin or the result of an abortive apoptotic mechanism. There may be some other protein which may useful indicator for predicting the sperm abnormality. HBPs themselves bind to spermatozoal membrane to make it stable (Manjunath and Therien, 2002). MogielnickaBrzozowska et al. (2011) indicated that boar seminal plasma proteins have a shielding effect on the plasma membrane and the acrosome of spermatozoa by protecting their structures against the damage caused by cold shock.

\section{Effect on sperm dna integrity}

There was no positive influence of HBP supplementation on sperm DNA integrity as observed in sperm morphology. This study showed a clear relationship between sperm morphology and DNA integrity. In particular, major sperm abnormalities appear to be closely associated with the presence of a highly damaged DNA molecule. Morphologically abnormal spermatozoa are more prone to DNA damage. A failure to address DNA damage in morphologically normal spermatozoa leads to misdiagnosis of male reproductive potential and an underestimate of male factor infertility (Enciso et al., 2011).

Exogenous addition of fertility associated proteins had shown to protect the sperm cells against the oxidative stress, which in turn helped to maintain DNA integrity (Maxwell and Johnson, 1999).

However, Saravia et al. (2009) carried out experiments on the influence of seminal plasma proteins on boar spermatozoa DNA integrity. They could not establish any significant effect on DNA stability of post thaw semen after treatment with seminal plasma.

In conclusion from this study, it is evident that HBP supplementation in capacitation medium did not alter the sperm morphology and DNA integrity. Extensive studies have to be carried out in determining the influence of HBP as such on sperm morphology and DNA integrity.

\section{Acknowledgement}

Authors are grateful to Tamil Nadu Veterinary and Animal Sciences University, Chennai-51 for providing necessary permission and financial assistance to carry out this study.

\section{References}

Amours, O. D., G. Frenette, M. Fortier, P. 
Leclerc and R. Sullivan, 2010. Proteomic comparison of detergent extracted sperm proteins from bulls with different fertility indexes. Reprod.139:545-556.

Arangasamy, A., L.P. Singh, N. Ahmed, M. R. Ansari and G.C. Ram, 2005. Isolation and characterization of heparin and gelatin binding buffalo seminal plasma proteins and their effect on cauda epididymal spermatozoa. Anim. Reprod. Sci.90(3-4): 243-254.

Ardon.,F and S. S. Sauarez, 2013. Cryopreservation increases coating of bull sperm by seminal plasma binder of sperm proteins BSP1, BSP3, and BSP5. 146: 111-117.

Brandon, C. I., G. L. Heusner, A. B. Caudle and R. A. H. Fayrer, 1999. Two dimensional polyacrylamide gel electrophoresis of equine seminal plasma proteins and their correlation with fertility. Theriogenology.52: 863-873.

Cameron,E., T.Day and L. Rowe, 2007 Sperm competition and the evolution of ejaculate composition.Am. Nat.169: 158-172.

Cancel,A.M., D. A. Chapman and G. J. Killian, 1997. Osteopontin is the 55-kilodalton fertility associated protein in Holstein bull seminal plasma. Biol. Reprod.57: 12931301.

Chakraborty, G., S. Jain, R. Behera, M. Ahmed,P.Sharma, V.Kumar and G. C Kundu, 2006. The multifaceted roles of osteopontin in cell signaling, tumor progression and angiogenesis. Curr Mol. Med.6: 819-830.

Chohan, K.R., J.T. Griffin and D.T. Carrell, 2004. Evaluation of chromatin integrity in human sperm using acridine orange staining with different fixatives and after cryopreservation. Andrologia. 36: 321326.

Enciso, M., H. Cisale, S.D. Johnston, J. Sarasa, J.L. Fernández and J. Gosálvez, 2011. Major morphological sperm abnormalities in the bull are related to sperm DNA damage, Theriogenology.76: 23-32.

Fouchecourt, S., S. Metayer, A. Locatelli, F. Dacheux and J. L. Dacheux, 2000.
Stallion epididymal fluid proteome: qualitative and quantitative characterization; secretion and dynamic changes of major proteins. Biol. Reprod.62: 1790-1803.

Jonakova, V., J.Jonak and M. Ticha, 2010. Proteomics of male seminal plasma. In: Zhihua J, Troy LO (Ed.). Reproductive genomics in domestic animals, WileyBlackwell, Iowa., 339-366.

Lane M., I. Therien, R. Moreau and P. Manjunath, 1999. Heparin and highdensity lipoprotein mediate bovine sperm capacitation by different mechanisms.60:169-175.

Lee, C. N., R. Handrow R, R.W. Lenz and R.L.Ax. 1985. Interactions of seminal plasma and Glycosaminoglycans on acrosome reactions in bovine spermatozoa in vitro. Gamete Res.12: 345-355.

Manjunath, P andI. Therien. 2002. Role of seminal plasma phospholipid binding proteins in sperm membrane lipid modification that occurs during capacitation. J. Reprod. Immunol.53: 109119.

Maxwell, W.M.C and L.A. Johnson, 1999. Physiology of spermatozoa at high dilution rates: the influence of seminal plasma. Theriogenology.52: 1353-1362.

McCauley, T. C., H. M. Zhang, M. E. Bellin, and R. X. Ax, 2001. Identification of a heparin-binding protein in bovine seminal fluid as tissue inhibitor of metalloproteinases-2. Mol. Reprod. Dev.58: 336-341.

Miller .D. J., M.A. Winer and R.L. Ax. 1990 Heparin-binding proteins from seminal plasma bind to bovine spermatozoa and modulate capacitation by heparin; Biol. Reprod.42:899-915

Miller .D. J., N.L. Firstand R.L. Ax . 1987 Isolation and characterization of seminal fluid proteins that bind heparin; Adv. Exp. Med. Biol.219:597-601.

Mogielnicka, B. M and W. Kordan, 2011.Characteristics of selected seminal plasma proteins and their application in the improvement of the reproductive 
processes in mammals. Pol.J. Vet. Sci.14(3): 489-99.

Mota Filho, A.C., H.V. Silva, T.G. Nunes, M. B. de Souza, L. A. de Freitas, A. A.de Araujo, andMoura, A.A., D.A. Chapman and G.J. Killian, 2006. Proteins of accessory sex glands associated with the oocyte-penetrating capacity of cauda epididymal sperm from Holstein bulls of documented fertility. Mol. Reprod. Dev.74: 214-22.

Moura, A. A., D. A. Chapman, H. Koc and G. J. Killian, 2006. Proteins of the cauda epididymal fluid associated with fertility of mature dairy bulls. J. Androl., 27: 534541.

Olaciregui, M. L., A. Gil, V.Monton, R.A. Luno, R, Jerez andJ. I. Marti, 2014. Cryopreservation of epididymal stallion sperm. Cryobiology. 68:91-95.

Parent, S., L. Lefievre, Y. Brindle and R. Sullivan, 1999. Bull subfertility is associated with low levels of a sperm membrane antigen. Mol. Reprod. Dev.52: 57-65.

Rangaswami, H., A. Bulbule and G. C. Kundu, 2006. Osteopontin: role in cell signalling and cancer progression. Trends Cell Biol. 16: 79-87.

Saling, P. M., 1989. Mammalian sperm interaction with extracellular matrices of the egg. In: S. R. Milligran (Ed.) Oxford Reviews of Reproductive Biology. pp 339-388.

Saravia, F., M. Wallgren , A. Johannisson, J.J. Calvete , L. Sanz , F.J. Pena , J. Roca, H.
Rodri'guez-Marti'nez, 2009. Exposure to the seminal plasma of different portions of the boar ejaculate modulates the survival of spermatozoa cryopreserved in MiniFlatPacks, 2009. Theriogenology.71: 662-675.

Schoneck, C., J. Braun and R. Einspanier, 1996. Sperm viability is influenced in vitro by the bovine seminal protein aSFP: effects on motility, mitochondrial activity and lipid

Theriogenology.45:633-642.

Shi,Y., D. D. Mosser, and R. I. Morimoto. 1998. Molecularchaperones as HSF1specific transcriptional repressors. Genes Dev. 12: 654-666.

Sprott, L. R., M, D. Harris, D. W. Forrest, J. Young, H. M. Zhang, J. N. Oyarzo, M. E. Bellin and R. L. Ax, 2000. Artificial insemination outcomes in beef females using bovine sperm with a detectable fertility-associated antigen. J.Anim.Sc. 78: 795-798

Varilova, T., H.Semenkova,P. Horak,M. Madera, V.Pacakova, M.Ticha and K. Stulik. 2006. Affinity liquid chromatography and capillary electrophoresis of seminal plasma proteins; J. Sep. Sci.29:1110-1115

Yanagimachi, R., $1988 . \quad$ Mammalian fertilization. In: E. Knobil and J. Neill (Ed.) The Physiology of Reproduction. Raven Press, New York., 135.

\section{How to cite this article:}

Yanben M. Kikon, K. Loganathasamy, V. S. Gomathy and Vijayarani, K. 2020. Sperm Morphology and DNA Integrity of Frozen Thawed Buffalo Semen Treated with Heparin Binding Protein. Int.J.Curr.Microbiol.App.Sci. 9(07): 3572-3579. doi: https://doi.org/10.20546/ijcmas.2020.907.417 